\title{
Immunocytochemical Demonstration of PHI and Its Co-existence with VIP in Intestinal Nerves of the Rat and Pig
}

\author{
Noboru Yanaihara, Kiyoshi Nokihara, Chizuko Yanaihara, ${ }^{1}$ \\ Toshihiko IwANAgA and Tsuneo FujITA ${ }^{2}$
}

Laboratory of Bioorganic Chemistry (Prof. N. YAnAihara), ${ }^{1}$ Shizuoka College of Pharmacy, Shizuoka and Department of Anatomy (Prof. T. Fujita), ${ }^{2}$ Niigata University School of Medicine, Niigata, Japan

Received June 1, 1983

\begin{abstract}
Summary. Immunocy tochemical studies of the rat and pig indicate that immunoreactivity for PHI (heptacosapeptide recently isolated by TATEMOTO and MUTT, 1981, from the porcine intestine) is located in numerous nerve fibers in the ileum and colon. Myenteric and submucosal plexuses contain abundant PHI-immunoreactive fibers. Alternate staining of adjacent sections with anti-PHI and anti-VIP sera indicates that PHI-immunoreactive nerves coincide with VIP nerves. This co-existence of both peptides in the same neurons may be accounted for by their probable sharing of a common precursor.
\end{abstract}

PHI is a 27 amino acid peptide recently isolated by TAтемото and MutT (1981) from the porcine intestine. The term was coined because it is a peptide $(\mathrm{P})$ with histidine $(\mathrm{H})$ at the $\mathrm{N}$-terminus and isoleucine (I) at the C-terminus. Its similarity to VIP (vasoactive intestinal peptide) in amino acid sequence prompts the hypothesis that $\mathrm{PHI}$ might share a precursor molecule with VIP, as in the case of the repetitive appearance of similar opioids in preproenkephalins (NoDA et al., 1982a, b; KAKIDANI et al., 1982; IKEDA et al., 1982) and anglerfish proglucagon (Lund et al., 1982). This hypothesis is supported by the radioimmunoassay studies by CHRIsTOFIDEs et al. (1982a), showing identical distribution of PHI- and VIP-like immunoreactivities in different tissues of different animals.

The present immunocytochemical study aims to detect the localization of PHI in the neuroendocrine system of the gut in comparison with that of VIP. The possibility of both peptides residing in the same neurons or paraneurons is examined.

\section{MATERIALS AND METHODS}

Male Wistar rats, weighing $200-250 \mathrm{~g}$, and castrated male pigs, weighing $5-10 \mathrm{~kg}$, were used in this study.

After being anesthetized with pentobarbiturate $(35 \mathrm{mg} / \mathrm{kg}$ in rats; $25 \mathrm{mg} / \mathrm{kg}$ in pigs), the animals were arterially perfused with Ringer's solution, then with $4 \%$ 
paraformaldehyde in $0.1 \mathrm{M}$ phosphate buffer ( $\mathrm{pH} 7.3$ ). The gut, from the gastric fundus to distal colon, was removed and tissue blocks from different portions were immersed in the same fixative for about $6 \mathrm{hrs}$.

The tissue blocks were immersed overnight in 30\% sucrose, frozen in dry iceacetone and sectioned in a cryostat at a thickness of about $15 \mu \mathrm{m}$. Serial sections of about a $6 \mu \mathrm{m}$ thickness were also prepared.

The sections were treated for $3 \mathrm{hrs}$ in $0.3 \%$ Triton X-100 in $0.01 \mathrm{M}$ phosphatebuffered saline and immunocytochemically stained with the PAP (peroxidase antiperoxidase) method according to STERNBERGER (1974).

The antisera used were: anti-PHI (20-27) serum (R8201) and anti-VIP serum (R502). Both sera were raised by injections of synthetic porcine PHI (20-27) and porcine VIP in rabbits, respectively. Synthetic porcine PHI-27 and PHI (20-27) were shown to crossreact equally with anti-PHI (20-27) serum R8201 in radioimmunoassay with the use of 125I-PHI-27 or ${ }^{125} \mathrm{I}-\mathrm{PHI}(20-27)$ as a tracer, and synthetic porcine VIP did not crossreact at all in the assay systems in doses of up to $200 \mathrm{ng}$. Natural porcine pancreatic glucagon (up to $200 \mathrm{ng}$ ) and synthetic porcine secretin (up to $25 \mathrm{ng}$ ) also showed no crossreaction with the antiserum in these systems. On the other hand, in VIP radioimmunoassay, neither synthetic porcine PHI-27 nor PHI (20-27) crossreacted with the anti-VIP serum $\mathrm{R} 502$ in doses of up to $3 \mu \mathrm{g}$. Characterization of antiserum R502 was previously reported (Yanaihara et al., 1977). Synthesis of porcine PHI-27 and PHI (20-27) and radioimmunoassay specific for PHI are to be described elsewhere. The anti-PHI serum was used primarily at a dilution of 4,000 times, while the anti-VIP serum was diluted 2,000 times. A specificity check of immunoreactions was performed by adding, before the reaction, $10 \mu \mathrm{g}$ of synthetic porcine PHI (20-27), synthetic porcine PHI-27, synthetic porcine VIP, natural porcine pancreatic glucagon or synthetic porcine secretin to $1 \mathrm{ml}$ of the diluted antisera.

\section{RESULTS}

In the gut of the rat and pig, the PHI-like immunoreactivity was found only in nerves and not in endocrine cells. Numerous nerve fibers could be clearly and selectively demonstrated by the anti-PHI serum. They were most abundant in the lamina propria mucosae of the ileum and colon (Fig. 1) and least in amount in the fundic mucosa of the stomach. Nerve fibers showing an identical distribution were demonstated with the anti-VIP serum.

In both animals, the myenteric plexus of Auerbach and the submucosal plexus of Meissner both contained a dense distribution of PHI- and VIP-immunoreactive fibers, which were thought to be mainly intrinsic nerves. Occasionally, neuronal somata immunoreactive for either peptide could be demonstrated.

The tunica muscularis received also numerous PHI-immunoreactive nerves. They were especially densely distributed in the interior circular muscles of the rat intestine. Here, the nerves ran parallel to the muscle fibers at fairly regular intervals. This pattern of nerve supply to the interior circular musculature was in precise accordance with that of VIP-immunoreactive nerves. Actually, examination of adjacent serial sections alternately stained with anti-PHI and anti-VIP antisera indicated that the same nerve fibers, and also the same neuronal somata, were immunoreactive for both peptides (Fig. 2).

Both in the rat and pig, the pyloric sphincter musculature was supplied with 


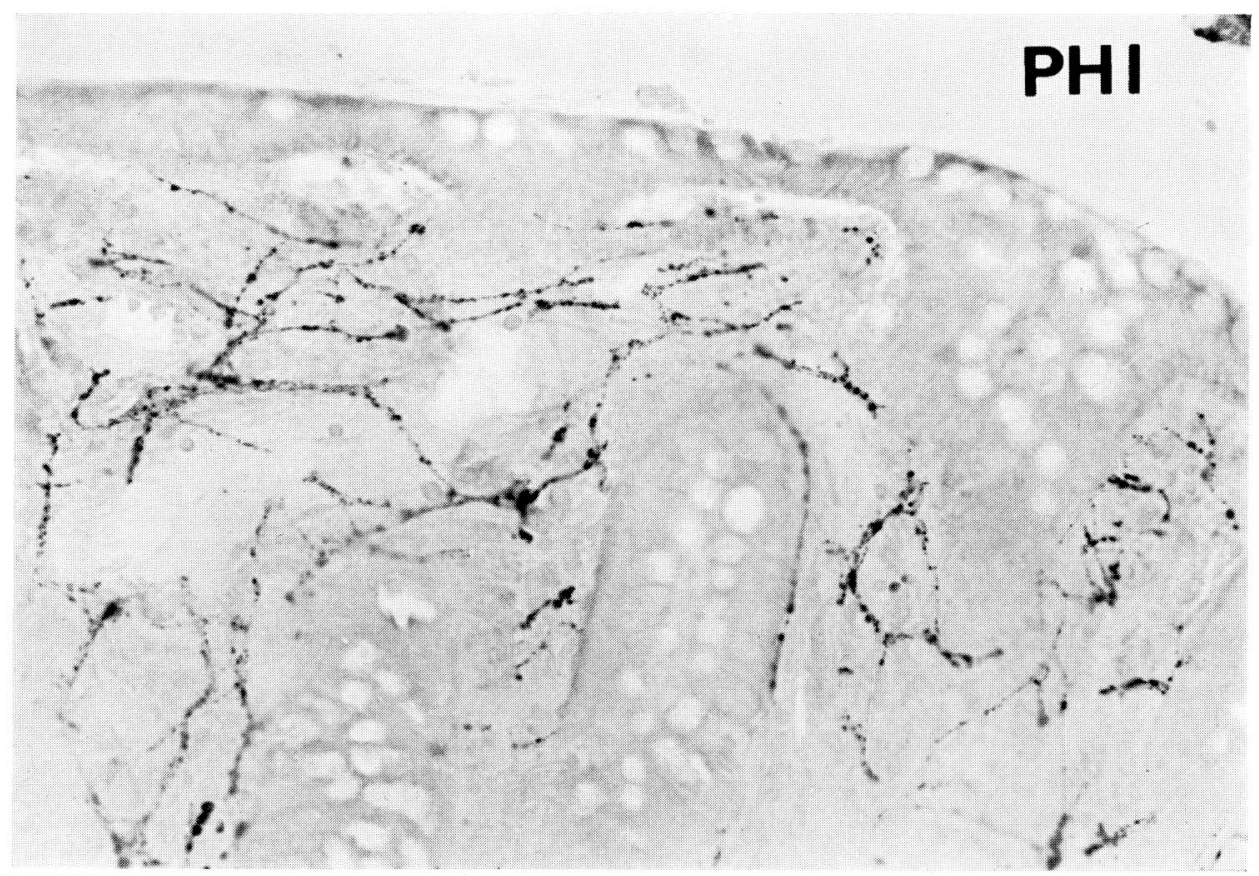

Fig. 1. A portion of the distal colon in the pig, showing PHI-like immunoreactive nerve fibers. $\times 280$

enormous amounts of PHI-immunoreactive fibers. Here again, the fibers corresponded to VIP-immunoreactive fibers.

Absorption tests were carefully performed in the tissues of the pig and rat. The immunoreactivity by the anti-PHI serum was completely abolished after addition of synthetic porcine PHI (20-27) and PHI-27 to the serum, but was not affected at all by the addition of synthetic porcine VIP, natural porcine pancreatic glucagon or synthetic porcine secretin. On the other hand, the immunoreactivity by the anti-VIP serum was inhibited after addition of synthetic VIP to the serum, but was not influenced by the addition of synthetic porcine PHI (20-27) or PHI-27.

\section{DISCUSSION}

PHI is a heptacosapeptide isolated from the porcine upper intestine (ТАтемото and MutT, 1981). Its primary structure resembles that of secretin and of VIP. Radioimmunoassay studies demonstrated its occurrence in the mammalian gut, respiratory tract and urogenital tract as well as in the brain (Christofides et al, $1982 \mathrm{a}, \mathrm{b}, \mathrm{c}$ ). The biological actions of PHI largely remain to be elucidated, though its secretin-like and VIP-like actions upon the watery secretion of the pancreas and intestine (Dimaline and Dockray, 1980; Anagnostides et al., 1982; Ghiglione et al., 1982), relaxation of tracheal and gallbladder smooth muscles (BREnNan et al., 1982; Christofides et al., 1982c) as well as insulin- and glucagon-releasing effects (Szecowka et al., 1981) have been documented.

In their radioimmunoassay study, Christofides et al. (1982a) found that the 


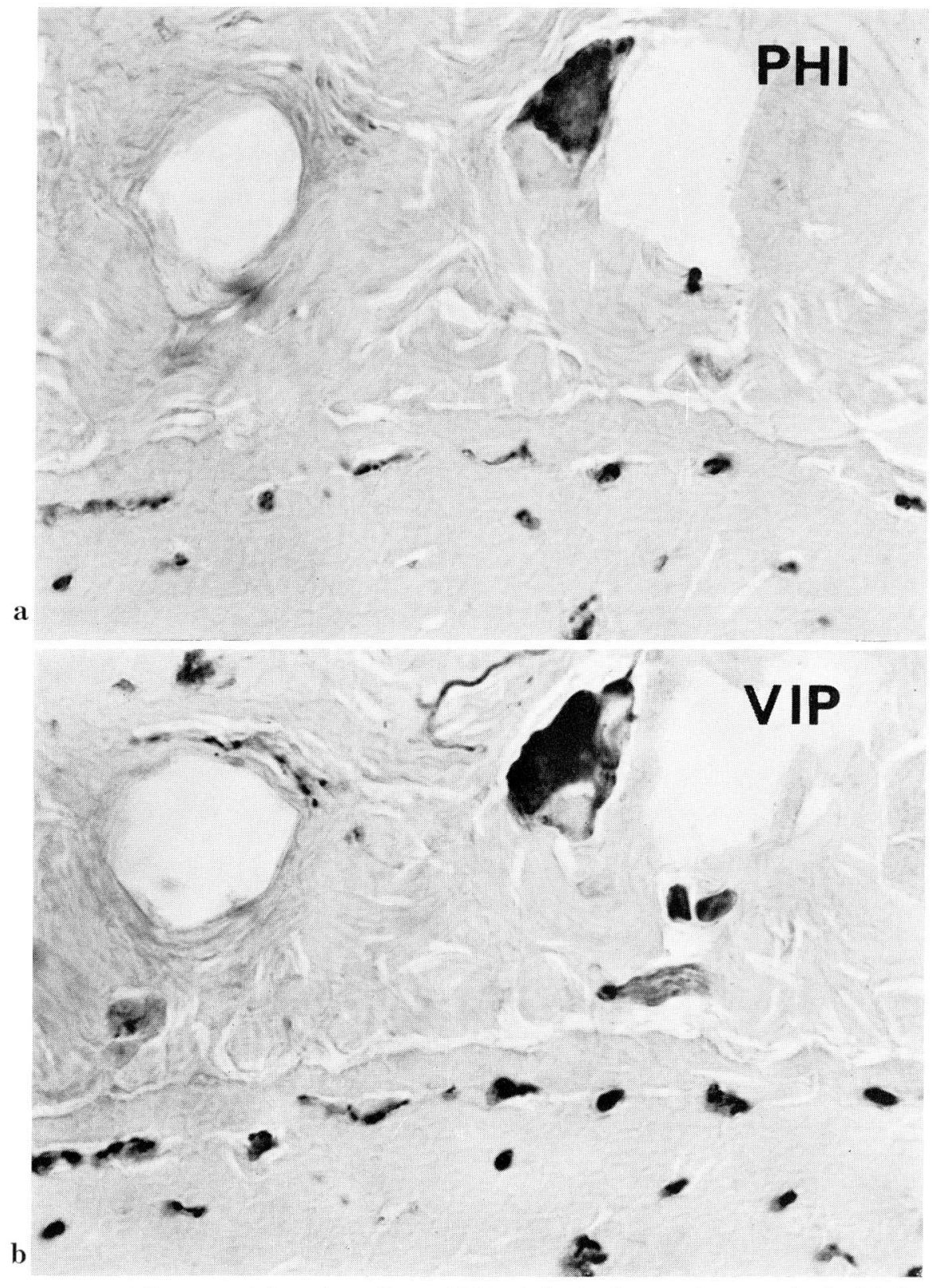

Fig. 2. Adjacent serial sections ( $6 \mu \mathrm{m}$ thick) of the duodenum of a rat stained with the anti-PHI serum (a) and with the anti-VIP serum (b). The same neuronal soma and fibers are immunostained by both antisera. The upper part of the pictures represents the submucosal tissue containing a plexus of Meissner (with a darkstained cytoplasm of a neuron), while the lower part the cross-cut inner muscle layer containing numerous immunoreactive fibers (dark dots). $\quad \times 800$ 
distribution of PHI-like immunoreactivity was identical with that of VIP-like immunoreactivity in different tissues of man, cat, guinea pig and rat. They postulated that PHI and VIP might possibly be co-synthesized in the same prohormone.

Immunocytochemical data have been available on the distribution of VIP-containing nerves in the digestive tract of mammals, including the rat (LARSSON et al., 1976; SundLer et al., 1978) and pig (SundLer et al., 1978; Malmfors et al., 1981). VIP nerves are one of the predominant nervous elements in the gut wall and are conspicuously numerous surrounding the intestinal crypts, along the core of the villi and penetrating into the inner circular musculature (LARSson et al., 1976; SundLER et al., 1978; Y ANAIHARA et al., 1980; MALmFors et al., 1981). They are especially condensed in the Oddi's and pyloric sphincters (Alumets et al., 1979). Numerous nerve fibers and some neuronal somata in Meissner's and Auerbach's plexuses have been known to be immunoreactive to VIP (LARsson et al., 1976; YanAihara et al., 1980; MalmFors et al., 1981).

The present immunocytological study of the rat and pig using highly specific PHI antiserum corresponded essentially to the reported distribution of VIP nerves. Moreover, the distribution of the VIP nerves was found completely in accord with that of the nerves containing PHI-like immunoreactivity. The co-existence of PHI- and VIPlike immunoreactivities in the same neurons could be brought into evidence by alternate stainings of adjacent sections with anti-PHI and anti-VIP sera.

It is now a most likely assumption that VIP and PHI share a common precursor or prohormone produced by a single messenger RNA. Very recently, the sequence analysis of the mRNA for the precursor of VIP revealed the probable co-existence of VIP with PHI (ITOH et al., 1983). We would then have a new example of multiple peptide co-existence in a neuron, due to the processing of a large prohormone molecule.

It is worthwhile to mention that VIP-immunoreactive nerves, at least in certain animals (e.g., cat) and in certain parts of the body (e.g., pancreas, salivary glands, autonomic ganglia, sweat glands and urinary bladder) have been reported to correspond to cholinergic nerves (LuNDBERG et al., 1979, 1980). We have also obtained evidence of this coincidence in rat intestinal nerves by comparison of adjacent sections stained for cholinesterase reaction and for VIP-immunoreactivity (IwANAGA, unpublished).

The present result deserves the special attention of physiologists and gastroenterologists because the VIP nerves which are so abundantly distributed in the gut, and which probably play important roles in the control of motility and secretion in the digestive system, corresponding in part, at least, to cholinergic nerves, have been revealed to contain, simultaneously, the PHI-like immunoreactivity. It appears reasonable to postulate that PHI released from these nerves might exert, possibly synergetically with VIP, significant influences upon the wide area of the digestive system. An immunocytochemical survey for PHI utilizing the urogenital tissues which are known to be another area richly supplied with and controlled by VIP nerves (ALm et al., 1977; VAALASTI et al., 1980) is presently in progress within our research group.

\section{REFERENCES}

Alm, P., J. Alumets, R. Håkanson and F. Sundler: Peptidergic (vasoactive intestinal peptide) nerves in the genitourinary tract. Neuroscience 2: 751-754 (1977).

Alumets, J., O. Schaffalitzky de Muckadell, J. Fahrenkrug, F. Sundler, R. Håkanson and 
R. Uddman : A rich VIP nerve supply is characteristic of sphincters. Nature 280: 155-156 (1979).

Anagnostides, A. A., K. Manolas, N. D. Christofides, Y. Yiangou, R. B. Welbourn, S. R. Bloom and V. S. Chadwick: Porcine histidine isoleucine (PHI) induces secretion in the pig small intestine. Gut 23: A 914 (1982).

Brennan, L. J., T. A. McLoughlin, V. Mutt, K. Tatemoto and J. R. Wood: Effects of PHI, a newly isolated peptide, on gallbladder function in the guinea pig. J. Physiol. (Lond). 329: 7172 (1982).

Christofides, N. D., Y. Yiangou, M. A. Blank, K. Tatemoto, J. M. Polak and S. R. Bloom: Are peptide histidine isoleucine and vasoactive intestinal peptide co-synthesized in the same pro-hormone? Lancet, December 18: 1398 (1982a).

Christofides, N. D., Y. Yiangou, G. P. McGregor, E. Aarons, P. L. Woodhams, K. Tatemoto and S. R. Bloom: Distribution of PHI in the rat brain. Biomed. Res. 3: 573-574 (1982b).

Christofides, N. D., Y. Yiangou, P. J. Piper, M. A. Chatei, K. Tatemoto, J. M. Polak and S. R. Bloom: Distribution of $\mathrm{PHI}$ in the mammalian respiratory tract and some aspects of its pharmacology. Regul. Pept. 4: 359 (1982c).

Dimaline, R. and G. J. Dockray: Actions of a new peptide from porcine intestine (PHI) on pancreatic secretion in the rat and turkey. Life Sci. 27: 1947-1951 (1980).

Ghiglione, M., N. D. Christofides, L. O. Uttenthal, K. Tatemoto and S. R. Bloom: Effects of the intestinal peptide PHI on net intestinal fluid transport in the rat. Gut 23: A 913 (1982).

Ikeda, Y., K. Nakao, T. Yoshimasa, N. Yanaihara, S. Numa and H. Imura : Existence of Metenkephalin-Arg ${ }^{6}-\mathrm{Gly}^{7}-\mathrm{Leu}^{8}$ with Met-enkephalin, Leu-enkephalin and Met-enkephalin-Arg ${ }^{6}-\mathrm{Phe}^{7}$ in the brain of guinea pig, rat and golden hamster. Biochem. biophys. Res. Commun. 107: 656662 (1982).

Itoh, N., K. Obata, N. Yanaihara and H. Okamoto: Human prepro-vasoactive intestinal polypeptide (VIP) mRNA contains the coding sequence for a novel PHI-27 like peptide, PHM-27. Nature (1983, in press).

Kakidani, H., Y. Furutani, H. Takahashi, M. Noda, Y. Morimoto, T. Hirose, M. Asai, S. Inayama, S. Nakanishi and S. Numa: Cloning and sequence analysis of cDNA for porcine $\beta$ neo-endorphin/dynorphin precursor. Nature 298: 245-249 (1982).

Larsson, L.-I., J. Fahrenkrug, O. Schaffalitzky de Muckadell, F. Sundler, R. Håkanson and J. F. Rehfeld: Localization of vasoactive intestinal polypeptide (VIP) to central and peripheral neurons. Proc. Nat. Acad. Sci. (USA) 73: 3197-3200 (1976).

Lund, P. K., R. H. Goodman, P. C. Dee and J. F. Habener: Pancreatic preproglucagon cDNA contains two glucagon-related coding sequences arranged in tandem. Proc. Nat. Acad. Sci. (USA) 79: 345-349 (1982).

Lundberg, J. M., T. Hökfelt, M. Schultzberg, K. Uvnäs-Wallenten, C. Köhler and S. I. Said : Occurrence of vasoactive intestinal polypeptide (VIP)-like immunoreactivity in certain cholinergic neurons of the cat: Evidence from combined immunohistochemistry and acetylcholinesterase staining. Neuroscience 4: 1539-1559 (1979).

Lundberg, J. M., A. Änggård, J. Fahrenkrug, T. Hökfelt and V. Mutt: Vasoactive intestinal polypeptide in cholinergic neurons of exocrine glands: Functional significance of coexisting transmitters for vasodilation and secretion. Proc. Nat. Acad. Sci. (USA) 77: 1651-1655 (1980).

Malmfors, G., S. Leander, E. Brodin, R. Håkanson, T. Holmin and F. Sundler: Peptidecontaining neurons intrinsic to the gut wall. An experimental study in the pig. Cell Tiss. Res. 214: 225-238 (1981).

Noda, M., Y. Furutani, H. Takahashi, M. Toyosato, T. Hirose, S. Inayama, S. Nakanishi and S. Numa: Cloning and sequence analysis of cDNA for bovine adrenal preproenkephalin. Nature 295: 202-206 (1982a).

Noda, M., Y. Teranishi, H. Takahashi, M. Toyosato, M. Notake, S. Nakanishi and S. Numa : Isolation and structural organization of the human preproenkephalin gene. Nature 297: 431-434 (1982b).

Sternberger, L. A.: Immunocytochemistry. Prentice Hall Inc., Englewood Cliffs, New Jersey, 1974. 
Sundler, F., J. Alumets, R. Håkanson, J. Fahrenkrug and O. Schaffalitzky de Muckadell : Peptidergic (VIP) nerves in the pancreas. Histochemistry 55: 173-176 (1978).

Szecowka, J., K. Tatemoto, V. Mutt and S. Efendic: Interaction of a newly isolated intestinal polypeptide (PHI) with glucose and arginine to effect the secretion of insulin and glucagon. Life Sci. 26: 435-438 (1981).

Tatemoto, K. and V. Mutt: Isolation and characterization of the intestinal peptide porcine PHI (PHI-27), a new member of the glucagon-secretin family. Proc. Nat. Acad. Sci. (USA) 78: 66036607 (1981).

Vaalasti, A., I. Linnoila and A. Hervonen: Immunohistochemical demonstration of VIP, (Met $\left.{ }^{5}\right)$ and $\left(\mathrm{Leu}^{5}\right)$-enkephalin immunoreactive nerve fibers in the human prostate and seminal vesicles. Histochemistry 66: 89-98 (1980).

Yanaihara, C., M. Sakagami, T. Mochizuki, H. Sato, N. Yanaihara, T. Iwanaga, S. Fujii and T. Fujita : Immunoreactive VIP (vasoactive intestinal polypeptide) in canine intestinal mucosa and muscle. Biomed. Res. 1: 449-455 (1980).

Yanaihara, N., M. Sakagami, H. Sato, K. Yamamoto, T. Hashimoto, C. Yanaihara, Z. Ito, K. Yamaguchi and K. Abe: Immunological aspects of secretin, substance P and VIP. Gastroenterology 72: 803-810 (1977).

矢内原昇

干422 静岡市小鹿 2-2-1

静岡薬科大学

生物薬品化学教室
Prof. Noboru Yanaihara

Laboratory of Bioorganic Chemistry

Shizuoka College of Pharmacy

Shizuoka, 422 Japan 